\title{
Interactions among Economic Ideas, Policies and Experience: the Establishment of Inflation Targeting in Canada, 1991-2001
}

\author{
DAVID LAIDLER \\ University of Western Ontario*
}

\begin{abstract}
In Canada, targeting the inflation rate was intended as a temporary measure during a transition to price-level stability, but became a well-established monetary policy regime in its own right. This paper analyses the role of the interaction of economic ideas with the experience generated by their application to policy in bringing about this outcome. In the following account, changing beliefs about the stability or otherwise of ongoing inflation, the capacity of a flexible exchange rate to create a vicious circle of depreciation and rising domestic prices, are emphasised, while ideas about the natural unemployment rate and money growth in influencing economic outcomes are also discussed. Today's standard theoretical approach to modelling inflation targeting arrived on the scene only as the Canadian regime was becoming well established.
\end{abstract}

Keywords: money, monetary policy, inflation, inflation-targeting, interest rates, unemployment, exchange rate.

JEL Classifications: B2, E5.

\section{Introduction}

The links between macroeconomic ideas and the conduct of inflation-targeting policy are extremely close these days, and anyone teaching serious students about this regime would certainly refer them to such long-established and basic theoretical works as, for example, Lars Svensson (1999), or Michael Woodford (2003), before turning to a discussion of the

\footnotetext{
* This paper derives from a lecture presented at the Guggenheim Conference on "Economic Research and Policy Making at the Federal Reserve in historical and international perspective" held at the Graduate Institute in Geneva on June 27th-28 ${ }^{\text {th }}, 2015$, where the author received the 2015 Thomas Guggenheim Prize for the History of Economic Thought. Its current form owes much to helpful advice and comments from Arie Arnon, Mike Belongia, John Crow, Chuck Freedman, Peter Howitt, Clark Leith, David Longworth, John Murray, Michael Parkin, Finn Poschmann, Bill Robson and Warren Young as well as from participants in the Geneva conference, but anything that the reader finds erroneous, misleading or misjudged in the text that follows is nevertheless the author's own responsibility.

(C2020 David Laidler. Licensed under the Creative Commons Attribution - Noncommercial 3.0 Licence (http://creativecommons.org/licenses/by-nc/3.0/. Available at http: //rofea.org.
} 
idiosyncrasies of any specific real-world examples, either existing or proposed. But it would be wrong to infer that the well-known macroeconomic theory we now associate with inflation targeting, which will be referred to as "the standard model" in this essay, was created in the academic literature before inflation targeting policies could be designed and implemented. ${ }^{1}$ Rather, as I hope to show, inflation targeting's origins lay in much older and less rigorous economic ideas, and the close links between academic theory and policy practice that characterise this regime nowadays evolved only slowly under the influence of events. In this paper I shall discuss this episode as an example of a more general process, namely the recursive interdependence of economic ideas, economic policies and economic experience whose significance for the place of the history of economic thought in macroeconomics I have explored in the past (see, e.g. Laidler 2003a, 2017),

The number of economies that nowadays rely on inflation targeting in some form or other runs well into double digits, and a full story of this regime's evolution in the international economy would involve all of them. But a single paper can only do so much, and in what follows, I shall discuss the development of a single regime, namely Canada's, following thematic as much as chronological lines. More specifically, always in the Canadian context and roughly over the regime's first decade (1991-2001), I shall outline the evolution of beliefs about: price stability as a policy goal and the stability of inflation; the exchange rate as a source of price level instability, and its role in monetary policy's transmission mechanism; and the places in the story of ideas about the natural unemployment rate as well as money growth. ${ }^{2}$

\footnotetext{
${ }^{1}$ The generic characteristics of this theory include: (i) a well-defined policy target, specifically a quantitative goal (typically, as in the case of Canada, with a band around it) for the rate of change of some price index over a more or less well-defined time interval (ii) a policy instrument under the control of the central bank, typically a very short-term nominal interest rate; (iii) an explicit dynamic stochastic equilibrium model of the mechanisms linking the behaviour of the target to that of the instrument in question, usually consisting of: (a) an expectations augmented Phillips curve, where the deviation of inflation from its expected rate varies with a so-called "output gap", (b) a function specifying the relationship between aggregate demand and the policy instrument, where the "real" interest rate that proximately affects the latter is linked to the policy instrument by a Fisher effect, and (c), a model (or equation) determining the time path of economy's productive capacity, which in conjunction with (b) determines the output gap; and (iv) a policy reaction function, often a so-called "Taylor rule" (see e.g. John Taylor 1993), specifying how the central bank does, or should, adjust its policy instrument in the light of information about the current and perhaps forecast behaviour of inflation and the output gap in order to keep the target variable on track.

${ }^{2}$ Note that I am concerned here with the processes by which inflation targeting initially achieved a secure place in Canada's macroeconomic policy framework, and not with the fascinating story of its subsequent encounter with the economic turbulence that marked subsequent years. Readers looking for discussion of these matters are referred to Steven Ambler and Jeremy Kronick's (2018) recent and definitive study of these later years.
} 


\section{LAIDLER Establishment of Inflation Targeting in Canada}

Though what follows can hardly claim to be definitive, therefore, by virtue of its focus on a single case of a much more widespread and heterogeneous history, I nevertheless hope that it will usefully illustrate the general nature of the processes that are always at work as ideas about how the economy functions and their influence on policy evolve in the light of experience.

\section{Price Stability and/or Low Inflation as Policy Goals}

Canada was the second country (after New Zealand, and before the UK) to adopt explicitly quantitative inflation targets. ${ }^{3}$ It did so in February 1991 with a joint announcement from the Bank of Canada and the Federal Government in its budget for that year. However, this announcement was not regarded, either by the Bank or by local academic and other commentators as heralding a new monetary policy regime. Rather, and at most, it seemed to be clarifying the nature and intended future course of a program that had been announced three years earlier, and already had attached to it a widely-used (though never in any communications emanating from the Bank of Canada itself) label, "zero inflation" (See Richard Lipsey (ed.) 1990).

\section{The 1988 Hanson Lecture and the 1991 Policy Announcement}

This program had been launched in a public lecture - specifically a contribution to the University of Alberta's Eric John Hanson Memorial Lecture Series, entitled "The Work of Canadian Monetary Policy" - delivered on January $18^{\text {th }} 1988$ by the Bank of Canada's then newly appointed (1987) Governor, John W. Crow (Crow 1988a).

There can be no doubt about this lecture's intended significance. Its text is said to have gone through more than thirty drafts before delivery (See Laidler and Robson 1993, p. 89, fn.), and in his foreword to it, Professor Brian Scarfe of the University of Alberta's economics department declared that "we believe that the governor's "Edmonton Manifesto" is of equal significance to the "Saskatoon Manifesto" of his predecessor, Mr. Gerald Bouey, which launched the strategy of monetary gradualism in the Fall of 1975" (Scarfe 1988, p.1, see also Bouey 1975). The lecture's fundamental message was also quite clear. Its second, (and first substantive) section bears the title "What To Do With Monetary Policy" [sic], and answers the query implicit here in its second paragraph, which reads in full:

\footnotetext{
${ }^{3}$ Charles Goodhart (2010) discusses the establishment of inflation targeting in these two other jurisdictions. The importance of strictly local circumstances in the relevant processes highlighted by Goodhart is striking, and is also a prominent feature of the Canadian story told in this paper.

${ }^{4}$ Crow (2002) has written his own account of central banking in Canada, and discusses the evolution of inflation targeting between 1988 and 1993 in Ch. 8 of this book, pp. 183-200
} 
"Theory and experience - much of this experience not overly cheerful but certainly instructive - both point to a very clear answer. Monetary policy should be conducted so as to achieve a pace of monetary expansion that promotes stability in the value of money. This means pursuing a policy aimed at achieving and maintaining stable prices" (Crow 1988a, p. 4)

It is hard to read this paragraph as an announcement that inflation targeting as we nowadays know it was about to begin. Its reference to "monetary expansion" now looks archaic, a point to which we shall return later, but, more important, it also fails to quantify the notion of stable prices or to set a timetable for their attainment. The difference here in matters of precision from later and still prevailing practice is stark. By 2001, the joint declaration about the future of monetary policy from the Canadian authorities would run as follows, only a little less terse and precise than its latest 2016 version. ${ }^{5}$

The inflation-control target range will continue to be 1 to 3 per cent;

Within this range monetary policy will continue to aim at keeping the trend of inflation at the 2 per cent mid-point;

The length of the agreement will be 5 years, until December 2006. Before the end of 2006, the Government and the Bank will review the experience over the period and determine the appropriate target for the period ahead. (Bank of Canada, 2001)

The February1991 joint announcement of "targets for reducing inflation" (Bank of Canada 1991), in whose genesis the Department of Finance rather than the Bank seems to have taken the lead (See Crow (2002), Don Drummond 2010), would bring the "zero inflation" program closer to later practice by setting specific goals, within a target range, for the inflation rate, and proposing a time path for their attainment as well. ${ }^{6} \mathrm{CPI}$ inflation, then running at more than 5

\footnotetext{
${ }^{5}$ Which reads: The target will continue to be defined in terms of the 12-month rate of change in the total CPI. The inflation target will continue to be the 2 per cent mid-point of the 1 to 3 per cent inflationcontrol-range. The agreement will run for another five-year period, ending 31 December 2021. (Bank of Canada 2016)

${ }^{6}$ We now know, thanks to Crow (2002) and Drummond (2010), that the quantification of monetary policy's goals was influenced by the then recent New Zealand example. We also know that the aims of the Bank of Canada and the Department of Finance were not the same. The Bank was intent on continuing its post-1988 drive towards price stability and was unenthusiastic about giving quantitative content to its goals. The Department of Finance, however, had more immediate short-run concerns. First, as we shall discuss below, late 1990 saw intense pressure on the exchange rate driven by uncertainty in financial markets about the durability of Canada's commitment to inflation reduction, and the Department believed that the announcement of explicit quantitative goals would help stabilize the situation. Second, the GST, a Federal value added tax, to be introduced in early 1991, was universally expected to give a once and for all boost to consumer prices, and with trade unions promising to push for offsetting wage increases, the Department, though willing to have the initial boost
} 


\section{LAIDLER Establishment of Inflation Targeting in Canada}

per cent, was to be gradually reduced to 3 per cent by the end of 1992 , to $2 \frac{1}{2}$ per cent by the middle of 1994, and 2 per cent by the end of 1995, all of these plus or minus 1 percentage point.

But something else was very much present in both the Hanson Lecture and this 1991 announcement which would go completely missing long before 2001: namely, an explicit invocation of the concept of price stability. Having specified an inflation reduction timetable, the 1991 announcement went on as follows, picking up the Hanson Lecture's theme: "Thereafter the objective would be further reductions in inflation until price stability is achieved"; and it then defined this state of affairs as a "rate of increase in the CPI that is clearly below 2 per cent", with the important qualification that further precision was not then being offered "in the event that further evidence becomes available over the next few years" (Bank of Canada 1991). In short, in the 1988 program as clarified in 1991, what we are now used to calling inflation targets were an intermediate means to attaining a more fundamental end, not a goal in and of themselves for Canada's future monetary policy regime.

When loosely specifying "price stability" as involving an inflation rate of less than 2 per cent, the 1991 announcement cited a recent study by Pierre Fortin (1990) of the accuracy of changes in the CPI as a measure of inflation; and other contributors to the symposium in which Fortin's work appeared (Lipsey, ed. 1990) had also suggested that in practice, allowing for biases in that index, which seemed to overestimate inflation by about 0.5 percent, "zero inflation" would mean allowing that index to increase at a rate in the range of $0-2$ percent per annum. In 1991 this specification was thus uncontroversial as a definition of price stability. As a goal for monetary policy, however, it certainly was.

\section{The disappearance of "price stability" as a policy goal}

From the outset in 1988, the Bank's aims had been much criticised by commentators who were nervous about the economy's ability to withstand monetary contraction of the scale needed to get inflation down, even gradually, from the $4-5$ percent range then prevailing to zero, and about the Bank's ability to stabilize it thereafter, not to mention about the political tensions that any regional disparities in such policies' impacts might create (see, e.g. Robert F. Lucas (1989), Thomas Courchene 1990a, 1990b). The fiscal situation also presented a problem: the Federal budget had been in chronic deficit since 1974, and the introduction of a contractionary monetary policy in the face of what looked likely to be continuing fiscal ease had obvious and unpalatable implications for the likely behaviour of interest rates. Such arguments found a wide and sympathetic audience, and the temperature of an already extremely heated public discussion of

accommodated by monetary policy, saw some advantage in announcing clearly that an ensuing wageprice spiral would not be tolerated. 
the Bank of Canada's "zero inflation" policy continued to rise uninterruptedly and rapidly after the 1991 announcement of formal targets.

Governor Crow's seven year term of office was to expire in early $1994 .{ }^{7}$ Co-incidentally but crucially, an election in late 1993 would - in a widely expected result - bring to power a Liberal government with no stake in the policy regime he had initiated, but to which a Conservative government had committed itself in its 1991 budget. Obviously both the Governor's position and the policy regime associated with him were politically vulnerable; and in the face of clear opposition from the new Minister of Finance, Mr. Paul Martin Jr., Crow withdrew his candidacy for reappointment. He was replaced by his deputy Gordon Thiessen, who, unlike Crow, found himself able to acquiesce in the new Minister of Finance's insistence that the goal of "further progress" after 1995, beyond 2 percent inflation and towards "price stability", be suspended (as a political trade-off against extending the 1995 two percent target until 1998), pending more study. ${ }^{8}$

The further progress in question has remained in suspension ever since, through five renewals of the initially interim 2 percent inflation target, the terms of four Governors of the Bank of Canada, seven federal elections, two major changes of governing party, not to mention a continuous sequence of debates, conferences, speeches, working papers, technical studies etc.. These facts raise a number of questions: Why was Governor Crow unwilling to accept any weakening of his price stability program in 1993 ? What had made this always politically vulnerable program completely untenable by then? And what happened thereafter to solidify an expedient short-run compromise, which at the time seemed simply to push a hard decision a couple of years into the future, into an enduring goal for Canadian monetary policy?

\footnotetext{
${ }^{7}$ The Bank of Canada Act gives sole authority over the conduct of monetary policy to the Governor, subject to (a) a requirement that he consult regularly with the Minister of Finance and (b) a ministerial over-ride power, which has to be implemented in writing, in specific terms, and expeditiously published, and which has never been utilised, because it is understood that this would trigger the Governor's immediate resignation, and hence precipitate a financial crisis. The Governor, whose appointment is renewable, holds office for seven years subject to "good behaviour"; that is, he can only be dismissed for malfeasance. He is appointed by a committee of the Bank's Board of Directors (political appointees with no monetary policy function) subject to the approval of the Cabinet, normally in the person of the Minister of Finance. In practice, therefore, a Minister's influence over a Governor's policy stance is at its maximum if and when he comes up for re-appointment, because he can then threaten to withhold approval of a recommendation for re-appointment by the Board. Crow (2002, ch.2.) deals with the rules under which the Bank operates, and their evolution in some detail .See also Laidler and Robson (1993, Ch. 3, and 2004, ch.2)

${ }^{8}$ The Board that initially recommended Crow's re-appointment, and then seems to have insisted on that of Thiessen, was made up of appointees of the just defeated Conservative government. This fact may be significant in explaining how so much of the earlier monetary policy regime came to survive the 1993 change of government.
} 


\section{LAIDLER Establishment of Inflation Targeting in Canada}

\section{Monetary Policy's search for a Place to Stand}

To understand Crow's intransigence, it is important to realise how important a landmark the 1988 Hanson lecture had been in the evolution of the Bank of Canada's thinking, coming as it did after almost two decades of policy uncertainty. ${ }^{9}$ In 1970 Canada had re-adopted a flexible exchange rate to ease the domestic monetary impacts of rising balance of payments surpluses, but policy makers had made the mistake of resisting the currency's subsequent appreciation thus ensuring that the country would participate fully in the great international inflation of the next decade. A formal policy of gradually restricting narrow money (M1) growth, adopted in 1975 with considerable fanfare - and a public endorsement from Milton Friedman (See Courchene (1976), p. 111) - accomplished little, and by 1980 inflation still hovered around the 10-11 per cent mark. Money growth targeting was thus already falling out of favour in Canada when the Volcker disinflation began in the United States, and the behaviour of the exchange rate, this time in the form of a rapid depreciation, again came to dominate policy as it had a decade earlier. Interest rates were dramatically increased, with the bank rate rising to slightly above 21 percent, and the exchange rate was steadied; but the targeted narrow money supply collapsed and so did the real economy and the inflation rate.

By the time the Bank's de facto abandonment of monetary gradualism in order to support the exchange rate was explicitly ratified ex post in 1982, the real economy was beginning to recover, and inflation would settled down in the 4-5 per cent range for the next few years. Crucially, however, nothing replaced narrow money growth targeting as the centrepiece of monetary policy. To invoke the title of Governor Gerald Bouey's Per Jacobsson Lecture of that year (Bouey 1982), its abandonment left Canadian monetary policy without "A Place to Stand" for the next six years, as the Bank's researchers undertook a vain quest for a reliable replacement. They were not the only ones, and in the mid-1980s, there was a flurry of interest among academics and others in proposals to replace targets for money growth altogether with targets for the growth path of nominal GDP. Alongside an array of alternative monetary aggregates to M1, this was also among the possibilities investigated in Bank research. ${ }^{10}$

But Bouey had already clearly hinted where the Bank's own search might end in the final sentences of his 1982 lecture:

\footnotetext{
${ }^{9}$ The story of monetary policy in the 1970 s and 1980 s, so briefly summarised here is told in more detail by Crow (2002, ch 7), and is dealt with extensively by Courchene (1975, 1976, 1977, 1978 and 1981) and Peter Howitt (1986). See also, Laidler and Robson (1993, ch. 6.)

${ }^{10}$ The important Macdonald Commission Report on The Economic Union and Development Prospects for Canada (see Royal Commission 1985) proposed such a goal as a medium term anchor for monetary policy. For Bank of Canada research on this topic, see David Longworth and Stephen Poloz (1986), and Pierre Duguay and Longworth (1998). I am indebted to David Longworth for helpful discussion of this episode.
} 
Since it has proven so hard to halt the process, we now know for certain that we should not give inflation a place to start. Economic performance over time will be better if monetary policy never loses sight of the goal of maintaining the value of money (p. 17)

Thereafter, the Bank's quest for a firm basis for a new regime slowly shifted away from a vain hunt for a more reliable intermediate target than M1, and towards the behaviour of the price level. In retrospect, this represented a reversion to almost forgotten ideas that had been canvassed in the interwar years. Then, Irving Fisher and his Stable Money League had promoted price stability as a legislated policy goal for the Fed. (See Fisher and Cohrssen (1934) for a retrospective account), and Henry Simons (1936) had argued for making it the basis of a monetary policy based on "rules" rather than "authorities".

But such ideas had been pushed into the background when, under the influence of the Great Depression and the Keynesian Revolution, interest in monetary policy waned. They had then been kept there, even after this interest revived, by Milton Friedman's powerful arguments (e.g. Friedman 1960,1968) that lags in the transmission mechanism of monetary impulses made the direct pursuit of goals for the price level futile or even dangerously destabilising, and that a growth-rate rule for the money supply, a key intermediate variable, was a therefore a preferable basis for policy. ${ }^{11}$ It was from these extremely influential- at-the-time ideas of Friedman's that the money-growth targeting regime implemented in 1975 had been somewhat loosely derived, and its abandonment in 1982 thus might have a prior claim over the Hanson lecture as marking the beginning of a process of fundamental change in the Bank of Canada's views on monetary policy. But that lecture's unequivocal declaration in favour of the old goal of price stability as a new place for monetary policy to stand was nevertheless a watershed in this process, drawing as it did widespread attention for the first time to what had become a critical and growing array of differences between those views and some of the important above-mentioned ideas that remained embedded in the period's mainstream academic macroeconomics.

\section{The feasibility of stable inflation as a policy option}

To complicate these differences further, the expectations-augmented Phillips curve (still an important component of today's "standard model" of inflation targeting) had arrived on the scene in the late 1960s, in two separate packages. In one, dispatched by Friedman (1968), it was accompanied by the argument that all monetary policy could control was the long-run average inflation rate - by way of setting a steady pace of money growth - while unemployment

\footnotetext{
${ }^{11}$ George Tavlas (2015) gives a convincing account of the role played by the analysis of policy leads and lags, and their capacity for generating instability, not to mention a large body of empirical evidence testifying to their importance amassed by Friedman and his co-workers, in differentiating Friedman's analysis of monetary policy rules from that of his Chicago predecessor Henry Simons.
} 


\section{LAIDLER Establishment of Inflation Targeting in Canada}

would have to be left to settle at its "natural" level, which might, however, be open to influence from microeconomic policies. In the other, launched by Edmund Phelps (1967, 1972), the same relationship was touted as the key component of a new "cost-benefit approach to monetary planning" in which the old static idea of a Phillips curve trade-off between inflation and unemployment was reconfigured in dynamic terms, with the latter variable creating the main costs to be incurred while efforts to reduce the inflation rate were in progress. Though Friedman's version is perhaps better remembered nowadays, in the 1970s, when the policy problem throughout the Western world seemed to be how to reduce inflation, Phelps' formulation arguably attracted more immediate attention in discussions of practical policy.

In particular, when combined with the then fashionable habit of measuring the gains to be had from reducing inflation in terms the areas of welfare-triangles under the demand for money function, which turned out in practice to be rather small - shoe-leather costs as James Tobin (1972) contemptuously dismissed them - this approach raised the possibility of simply learning to live with an already deeply embedded inflation rate as a serious policy option. This latter position attracted considerable support, so much so that the idea that the Bank of Canada should settle for stabilising the inflation rate at its then current value of a little over 4 percent was the clear target of Crow's insistence in 1988 that

"the notion of a high, yet stable, rate of inflation is simply unrealistic . . . If the authorities were unwilling to act to get the rate of inflation down from, for example 4 per cent, why should anyone believe they would be any more willing to get it back to 4 per cent if for one reason or another upward pressure on prices led the inflation rate to rise to 5 per cent? And so on",

Hence "the only realistic policy we can pursue that will generate and warrant confidence in the future value of money is to work towards price stability" (1988a p. 5).

The idea that "creeping inflation", if tolerated, would always threaten to evolve into "trotting inflation", and perhaps ultimately to break into a "gallop" - here I borrow vocabulary used by one of its most distinguished earlier exponents, Gottfried von Haberler (1961) - and hence could not be a credible policy goal, was hardly new when Crow invoked it in 1988. Indeed, by then it had been academically unfashionable for twenty years or so. Richard Lipsey had dismissed it as a "very commonly believed piece of folklore" albeit without citing a source, as early as 1963, in the very first edition of his famous introductory textbook (See Lipsey 1963, p. 430). But this is hardly the first time that an old idea has resurfaced and become influential in the history of macroeconomics, and this one did both, at a crucial moment in the history of Canadian monetary policy. As the above quotation confirms, it was the main basis for Crow's commitment to price stability as a place for monetary policy to stand in 1988, and it also 
underpinned his unwillingness to cede this long-run commitment to what he saw as short-run political expediency in 1993.

But this same idea made little impact among Canadian macroeconomists when Crow resurrected it. Scepticism about it figured prominently not only among his many critics, but also among those more sympathetic to his belief that, at the turn of the decade, inflation was too high. Among the latter, Lipsey (1990), though stressing the considerable capacity of even an apparently "low" inflation rate of 4 per cent to erode nominal wealth and fixed money incomes, also discussed the Bank's proposed policies in terms of an essentially Phelpsian dynamic trade-off between its immediate costs and longer term benefits. So did Douglas Purvis (1990) and Peter Howitt (1990). Purvis (1990) accepted Crow's argument that inflation in the 4-5 per cent range was too high to be credible, and agreed that the Bank should gradually reduce it from this level, but he saw no reason for this reduction to be carried all the way to zero. Like the Bank, he believed that the credibility of a commitment to stable inflation would increase as it fell, but unlike the Bank, he suggested that the question of whether inflation reduction could safely stop short of price stability could be left open for a while.

Howitt analysed the Canadian situation in a similarly explicit Phelpsian manner, but he assessed the costs of inflation, not in terms of triangles under a demand for money function, but of the more pervasive distortions that menu-cost related fluctuations in relative prices, whose effects were amplified by a largely unindexed tax system, could generate as inflation progressed. And he supplemented this treatment - which followed lines that Courchene (1981), citing, as did Howitt, Axel Leijonhufvud (1977), had introduced into the Canadian debate a decade earlier - with a relatively new twist. Referring to recent developments in endogenous growth theory (see Howitt p.99, fn), he suggested that, because investment was the means whereby new productivity-enhancing technology was brought into use, and because higher inflation undermined the efficiency of this activity, reducing it was likely to raise not just the level of output (a claim that had been made in the Hanson lecture) but its rate of growth as well.

Given the capacity of even small increases in the rate of growth of an income stream to increase its present value, this argument tipped the verdict of Howitt's analysis, which attracted much attention in the next few years, strongly in favour of moving from the status quo 5 percent inflation of 1990 towards a significantly lower rate; but still, and in agreement with Purvis, Howitt explicitly pointed out that, because the marginal benefits of reducing inflation would decrease as it fell, while the marginal costs were likely to remain constant, it stopped short of establishing the total elimination of inflation as the only reasonable long run goal for monetary policy. $^{12}$

\footnotetext{
${ }^{12}$ Unusually for a Canadian policy study, Howitt's work attracted attention within the Federal Reserve System (see. Daniel Thornton 1996). It cited a well-known Bank of Canada study by Peter Jarrett and Jack Selody (1982) of the inter-relationships between inflation and productivity growth in the 1960s and 1970s that seemed to suggest that the gains to be realised here were significant. The Bank's own
} 


\section{LAIDLER Establishment of Inflation Targeting in Canada}

The important point here is that, unlike the older views that underlay the Bank's view of inflation, this newer Phelpsian analysis implied that no deep economic principles were being violated when, in 1993, a new Minister of Finance refused to support more ambitious post-1995 goals for price stability. While Crow's view of matters in 1993 focussed on the loss of what he regarded as the essential element of his monetary policy program, therefore, the majority of his academic supporters focussed instead on the fact that a 2 percent inflation target to be reached over the next couple of years was still in place. They were relieved that what they had always regarded as important about his program, its inflation reduction, as opposed to its inflation elimination, element, had been preserved in the face of considerable academic criticism and political opposition.

\section{The Contraction of 1990-91 and its Aftermath}

At the turn of 1993-94, while all this was happening, the Canadian economy was well into the second year of what would prove to be an agonisingly slow recovery from a recession that had struck suddenly in late 1990 and (unlike the mild US contraction of that year) had been almost as deep as that of 1981 - with a peak unemployment rate of a little over 11 per cent.

\section{The exchange rate's role in the contraction}

This contraction, and in particular its severity, was widely and immediately attributed to monetary policy. It was hardly surprising, then, that explicit targets for inflation-reduction as a prelude to price-stability, which had been set in while it was in progress, would suffer politically by association when a new government came to power. In fact, however, the monetary contraction responsible for the recession's severity had begun well before these targets were put in place, and stemmed not from an obsessive over-eagerness on the part of the Bank of Canada to get moving along the road to a soon to be quantified price stability goal, as many of its critics suggested, but from a desire to protect its own and its program's credibility against what it perceived to be a threat from foreign exchange markets. Here the main ideas influencing the Bank's actions were not so much about the virtues of price stability per se, but about the role of the exchange rate in the monetary policy process.

continuing interest in this theme is epitomised by Selody (1990). In hindsight it seems likely that these results, which did not prove robust, were heavily affected by the fact that a significant secular slowdown in productivity growth in the mid-1970s coincided with the arrival of double digit inflation. A later study of international evidence on this issue by Robert J. Barro (1996) carried out for the Bank of England found that such relationships became harder to discern as inflation rates sank into the single digit range. For a well-balanced retrospective account of the rise and fall of Canadian economists' confidence in the productivity and productivity growth gains to be realised from low inflation, written against the background of Canada's policy regime, see Christopher Ragan (1998). See also, Laidler and Robson (2004, pp. 150-155) 
After the Hanson lecture, and further remarks delivered by Crow at the 1988 meetings of the Canadian Economics Association (Crow 1988b) that confirmed that this lecture was indeed to be taken seriously, monetary tightening had tentatively begun in the second half of the year, and by 1989 had become firm enough to attract widespread attention, much of it critical, as both interest rates and the exchange rate moved up. By late 1989, however, demand pressures in the economy showed signs of slackening, at least to careful observers such as Governor Crow and his colleagues. A little monetary easing seemed to be called for, and was duly applied. ${ }^{13}$

Unfortunately, this easing, modest though it was, was widely read in financial markets not as an indication that policy was on track, but that the Governor's resolution to see his price stability program through was weakening. The exchange rate fell by two cents in a week and a further two within the month. The Bank responded not just by reversing its monetary easing but by tightening policy significantly relative to where it had been over the previous year. It held this new stance well into 1990, with bank rate peaking at just over 14 per cent in May, even as the exchange rate stabilised and then moved up; and the narrow money supply collapsed just as it had in 1981. The resulting slump, already visible when inflation control targets were announced in February 1991, would reach its trough in the second quarter of that year, and by the beginning of 1992, inflation, which had been running at 5-6 percent a year earlier, came in at just under 2 percent, the figure that had been targeted for the end of $1995 .{ }^{14}$

\section{Ideas about the exchange rate's policy-significance}

It is hard to deny that Bank of Canada policies were the proximate cause of most of this, or that in redirecting policy towards the short-term behaviour of the exchange rate in 1990, the Bank undermined its own longer-term strategy for the price level. But there was nothing improvised about the measures it had taken. They were clearly foreshadowed in the Hanson Lecture, which had paid careful attention to the place of the exchange rate in the determination of the price level and more generally in the mechanisms through which monetary policy affected the economy. Reflecting on the situation that had prevailed in the mid-1980s, Crow had remarked that

the main risk on the inflation front was from price shocks caused by exchange rate movements. These shocks might have led to a resurgence of inflationary expectations and greater upward pressure on prices ... the avoidance of sharp

\footnotetext{
${ }^{13}$ This episode is described in more detail by Laidler and Robson (1993, Ch. 7)

${ }^{14}$ CPI Inflation data for 1991-2 are distorted by the introduction of the GST at the beginning of 1991. The measured year on year rate in the month the tax was introduced was a little over 6 per cent, with a percentage point of this probably being attributable to the tax. When its effects dropped out of the index 12 months later, the rate came in at just under 2 per cent.
} 


\section{LAIDLER Establishment of Inflation Targeting in Canada}

depreciations of the exchange rate therefore received a good deal of weight in monetary policy decisions (Crow 1988a, p. 20)

And then, turning to the future, he had assured his audience that

we have to take account of movements in our exchange rate on the pace of spending and of inflation in our economy. This is so even if our goal is not the external value but rather the domestic value of the Canadian dollar, and even if the surest way to sustain the exchange value of our currency is to maintain its purchasing power at home. . . let me underline that monetary policy will always to be ready to act, and act promptly, to backstop confidence in the Canadian dollar. Such confidence, once dissipated, is not easily regained. (Crow 1988a, pp.23-24)

At the beginning of 1990, believing that confidence in the currency was indeed weakening fast and threatening to set in motion a vicious circle of depreciation and domestic inflation, this is exactly what the Bank of Canada did

We do not need to reach a verdict here on whether the Bank of Canada had any option but to react as it did in 1990 (though some supporters of its overall program thought at the time that a more measured reaction would have been both feasible and desirable: see, e.g. Laidler and Robson 1993, p 104). And it should be noted that there were several good reasons, completely unrelated to monetary policy, for confidence in the currency be to particularly weak at that time. ${ }^{15}$ Indeed in 1990, it was not even clear that the Bank of Canada's price stability program had the support of the government of the day. As one of Crow's more perceptive critics (David Johnson 1990) had noted, the inflation forecasts embedded in the 1990 budget lay significantly above any time path that was consistent with the Bank's declared intentions.

Rather, what is crucial to the argument of this paper is that there was nothing novel about the ideas that drove the reaction in question. Similar concerns had underlain the Bank's setting aside its gradualist money growth policies in order to support the exchange rate in 1981 (see, Bouey 1982 pp. 13-14), and the idea that speculation-driven exchange rate depreciation could be an essentially independent driver of domestic inflation had an even longer intellectual

\footnotetext{
${ }^{15}$ Among these reasons were the following: the 1987 Meech Lake Accord -a federal-provincial agreement on fundamental constitutional reform - was clearly in trouble by 1989 , and in fact failed to be ratified in 1990, setting in train a more or less continuous series of internal political shocks that would culminate in the 1995 Quebec referendum on separation, which came within a hairsbreadth of breaking up the country; the Federal budget remained in chronic deficit, and the higher interest rates associated with the Bank's policies were putting it under increasing strain, even before the defence of the exchange rate made these intense; the next election looked increasingly likely to bring to power a new Liberal government pledged to abolish the newly introduced GST and to renegotiate the North American Free Trade agreement, but whose leaders had said nothing about how they intended to replace these newly erected pillars of Canadian fiscal and trade policy.
} 
pedigree. Even six decades earlier, a version of just such a mechanism had been widely touted as an explanation of the Weimar hyper-inflation (see Laidler and George Stadler 1998 pp. 142144); and this analysis was also closely related to notions about the dangers of destabilizing speculation that had figured prominently in the influential League of Nations sponsored study of inter-war exchange rate instability by Ragnar Nurkse (1944).

The latter study had, of course, drawn criticism from Milton Friedman (1953), who argued that the observed exchange rate instability of the inter-war years was the side effect of unstable domestic monetary policies, inconsistent across countries, rather than the product of an inherent flaw in the workings of the foreign exchange market itself. But if the well-established ideas that motivated and guided Canadian monetary policy in 1989-91 were not the only ones available in the academic literature of the time, they nevertheless prevailed, at least for the time being. ${ }^{16}$ We shall take up this story again below, but first we need to discuss an alternative explanation of the Bank's behaviour in the early ' 90 s that has gained considerable currency.

\section{The natural unemployment rate hypothesis}

To be specific, the foregoing account of the role of economic ideas in bringing about Canada's 1990-91 recession is very unlike that told by George Akerlof and Robert Shiller (2009). These authors also lay the proximate blame for events squarely on restrictive monetary policy, but they differ in their assessment of the economic theory that drove its conduct. Here, following Fortin (1996), they assign pride of place, not to beliefs about the role of the exchange rate, but to the natural unemployment rate hypothesis. In their words, "Crow was a firm believer in natural rate theory and the ability of the central bank to bring inflation down. And he was successful in this task ... but at a terrible cost" (p.114). They then go on to blame a Canadian slump that they suggest lasted till the end of the decade - a stretched interpretation of the evidence, particularly that generated after 1995 - on the continued pursuit of low inflation after 1994 by Crow's successor Gordon Thiessen, which they allege was also underpinned by an "ideological" belief in the natural rate hypothesis. ${ }^{17}$

As already noted above, the idea that there is no long-run inflation unemployment trade off was a highly visible feature of Friedman's (1968) exposition of the expectations augmented Phillips curve (and of Phelps' version too). From the outset, this idea was controversial and

\footnotetext{
${ }^{16}$ It should be recalled though, that in the wake of the two decades of gyrating exchange rates that followed the breakdown of the Bretton Woods system, confidence in the stability of the foreign exchange market was at a low ebb at the beginning of the 1990s. Whether this experience, which to the best of my recollection, none of the supporters of flexible rates had anticipated or found themselves able to explain at the time, can actually be explained in terms of inconsistencies among the then current and prospective policies of the countries involved is a question that I would prefer not to tackle here.

${ }^{17}$ Akerlof and Shiller do not cite Crow (2002) in the course of their attack on his policies.
} 


\section{LAIDLER Establishment of Inflation Targeting in Canada}

open to plausible criticism. Particularly significant in the current context is an idea advanced by James Tobin (1972) among others - though, as James Forder (2014) has pointed out, it seems to have originated in ideas about "demand shift inflation" first promulgated by, among others Charles Schultze (see, e.g. 1959). Its basis was the suggestion that the money wage setting processes might be subject to extra downward rigidities in the region of zero change that would make it particularly difficult for wage relativities to adjust to variations in the structure of the demand for labour at low inflation rates. If this was the case, then there would still be a long-run trade-off between inflation and unemployment at those lower rates.

Such effects were and remain undeniably possible, but what really mattered in the 1990s, as now, was their quantitative significance. They had attracted little attention in the high-inflation 1970s for obvious reasons, but, by the late 1980s, with inflation running in low single digits, they were once again potentially relevant to the design of a monetary policy initially intended to eliminate inflation altogether. Even so, to judge from the Hanson Lecture, they do not seem to have attracted the Bank of Canada's attention at the time. On the other hand, however, that lecture and related announcements made no explicit declaration of faith in the natural unemployment rate hypothesis either. ${ }^{18}$

To be sure, in the Hanson lecture and elsewhere, Crow had argued that there were no gains to be had for the economy in taking a permanently relaxed attitude to inflation, and maybe some losses to be incurred too. But it is doubtful that the main inspiration here was Friedman (1968) or Phelps (1967). It is far more likely that Crow was following examples of scepticism about the alleged benefits of inflation that had been set, among others, by an earlier Governor of the Bank, James Coyne, whose career had foundered in 1960, in part on his commitment to this idea. Similar scepticism had been expressed by the Porter Commission (see Royal Commission on Banking and Finance, 1964) which had reported comprehensively on the workings of the Canadian monetary system in the wake of the crisis that had followed Coyne's resignation, and whose discussions of this issue Crow's deputy and eventual successor Gordon Thiessen would later term "prescient" (see, Thiessen 1999, p.47). ${ }^{19}$

\section{Money wage stickiness}

Had policy followed its initially intended gradual path after 1988, none of this would have mattered much; but as we have seen, the sudden and sharp tightening of 1990 and the recession

\footnotetext{
${ }^{18}$ Though some of its academic supporters did: Purvis (1990 pp. 37-38), for example, was one of these, though he qualified his invocation of the idea with an explicit warning that it might take five years or more for "temporary effects" to dissipate after a monetary contraction

${ }^{19}$ Crow (2002, chs. 1 and 2) discusses these episodes and their implications. James Powell (2009) gives a fuller account of the so called "Coyne Affair". On the Porter Commission more generally, also see Thiessen (1999)
} 
that it caused changed the landscape entirely. With inflation falling to a range not observed since the 1960s, the possibility that wage-stickiness would have adverse effects on the long run level of unemployment increased and soon attracted attention. A working paper on the topic, Fortin (1995) was soon in circulation, and though its results were not actually published under Fortin's own authorship until the following November (see Fortin 1996), they attracted immediate and widespread attention long before that. They were a prime exhibit in Akerlof, Dickens and Perry's (1996) still well known, and successful, attempt to revive interest in Tobin's (1972) critique of the natural unemployment rate hypothesis, and were also cited by Paul Krugman (1996) in an essay entitled "Stable Prices and Fast Growth, Just Say No" written for The Economist. Much later, moreover, Fortin (1995 and 1996) were the only sources cited in by Akerlof and Shiller (2009) in their account of the role played by the natural unemployment rate idea in shaping Canadian economic policy and history in the 1990s.

Fortin (1995) had found that a much larger fraction - Krugman termed it a "staggering 47 percent" - of union wage bargains that did not include cost of living adjustment clauses had settled on no change in money wages during the low inflation years of 1992-94 than during the higher inflation years of 1986-88 - around 12 percent. Applying Tobin's (1972) analysis, and referring back to his own earlier working paper and to Akerlof, Dickens and Perry's (1996) by then published discussion of these matters, Fortin (1996) argued that these results implied the existence of a significant negative relationship between inflation and the long-run unemployment rate in Canada at inflation rates below 3 percent. Hence, he concluded, not only had monetary policy been responsible for the 1990-91 downturn, but a continuing policy aimed at a 2 percent inflation rate was condemning the country to continuing high unemployment and poor economic performance into the foreseeable future.

Readers of Akerlof and Shiller's (2009) have been left with the impression that Fortin's gloomy forecasts were both robust and vindicated by subsequent experience. But in fact his results had been quickly and persuasively challenged, not least by Bank of Canada researchers, as being heavily dependent on particular and controversial decisions about the selection and organisation of the relevant data (See, for example, Seamus Hogan (1997), Allan Crawford and Alan Harrison (1998), and Charles Freedman and Tiff Macklem 1998). For example, when alternative, and arguably more plausible, formulations were deployed, Fortin's "staggering" 47 per cent figure for zero wage changes in contracts negotiated in 1992-94 fell well below 20 per cent. ${ }^{20}$ And crucially for the topic of this paper, these data adjustments were also more than

\footnotetext{
${ }^{20}$ Though Tobin's initial analysis was cast in terms of the behaviour of private sector labour markets, Fortin's data set included many public sector agreements, including some from the province of Ontario in the 1992-94 period in which wage freezes had not emerged from any bargaining process, but had been imposed by government decree. Only the first year outcomes of multi-year contracts were counted, even where the first year in question involved grandfathering what had already happened because of bargaining delays and produced an automatic "no-change" observation, and even where wage increases or cuts for later years formed part of the overall bargain.
} 


\section{LAIDLER Establishment of Inflation Targeting in Canada}

adequate to shift the inflation rate at which Tobin style effects on the long inflationunemployment rate-off became important to less than 2 percent.

Even so, and after these adjustments, the data still revealed an unusual bunching of wage settlements around zero, and hence gave some qualitative support to concerns about how the labour market would perform at an inflation rate below 2 percent. Crucially, then, they also opened up questions about the long run employment costs of shifting monetary policy towards a more ambitious inflation goal than the then-still-interim 2 percent target. Moreover, the productivity and productivity growth gains that had been widely expected from reducing inflation from the 5 to the 2 percent range, and which had underpinned Howitt's (1990) endorsement of this goal, simply had not materialised by the later 1990s. All in all, the facts reported here changed perceptions of the Phelpsian trade-off in low inflation regions to an extent that made "further progress" towards price stability beyond the 2 per cent range look much less attractive. Ironically then, and quite contrary to Akerlof and Shiller's claims, if questions raised by the natural unemployment rate hypothesis had any direct influence at all on Canadian monetary policy in the 1990s, it was to discourage the Bank of Canada from trying to renew its original quest for price stability as the turn of the millennium approached.

\section{The Exchange Rate's Shifting Place in the Policy Framework}

The three most significant post-war episodes of monetary instability in Canada - the onset of inflation after 1970, and the two slumps of 1981-2 and 1990-91 were all, or so it has been argued here, heavily influenced by the Bank of Canada's becoming distracted from its domestic goals by the behaviour of the exchange rate. Nor, despite this experience, was the Bank quite immune to such temptations later in the $1990 \mathrm{~s}^{21}$ Fears of exchange rate depreciation that might generate extrapolative expectations and lead on to a vicious circle of inflation and further depreciation were still aired in speeches by the Governor, notably for example in Thiessen (1995), while the Tequila crisis of early 1995 and the Russian crisis of 1998 both brought the Canadian dollar under external pressure, and drew responses from the Bank in the form of domestic monetary tightening.

These responses were relatively short-lived, however, particularly in the second instance. Perhaps this was because some of the non-monetary factors that had contributed to the fragility of confidence in the Canadian economy in 1990-91 were already beginning to become less significant by the middle of the decade, though this did not prevent the Canadian dollar

\footnotetext{
${ }^{21}$ Laidler and Robson, (2004, pp.155-173) give a more detailed account than space permits here of the exchange rate's behaviour as well as its influence on policy debates and policy itself during this period.
} 
attracting in some quarters the nickname "Hudson Bay Peso" for a while. ${ }^{22}$ But, more likely, and here we have an example of how events, having been influenced by ideas, can in turn cause the latter to change, the Bank had learned some lessons from earlier episodes about the dangers of allowing the short-run behaviour of the exchange rate to distract its attention from longerterm goals.

\section{The monetary conditions index}

The exchange rate had been discussed not just as a potential source of exogenous monetary disturbance in the Hanson lecture, but also as a key variable in the monetary policy transmission mechanism. That lecture's account of this mechanism amounted to an early version of an open economy variation on the one, centered on the influence of interest rates on aggregate demand, embodied in today's standard model. In this context, the exchange rate would feature prominently not only in the Bank of Canada's conduct of policy, but also in its efforts to communicate its policy intentions to the public at large, well into the 1990s. As early as 1990, (See Charles Freedman 1994) the Bank began to construct, and would soon after begin to publish, a "Monetary Conditions Index" (MCI) in which estimates of the relative importance of interest rate and exchange rate movements for aggregate demand were quantified and blended into a single number. ${ }^{23}$

For a while this index became an informal but apparently important intermediate target for monetary policy. It played the same role as that of some representative market interest rate, or rates, in the closed economy systems of the time, which were by then coming more and more to resemble today's standard model, and which Bank researchers, building on their own contributions to these developments, were adapting to local requirements. ${ }^{24}$ The target value of the MCI was thus never intended to be a constant, as Bank of Canada communications repeated ad nauseam in the mid-1990s. Rather, policy actions were geared to adjusting the

\footnotetext{
${ }^{22}$ By 1995 inflation targets had been in place for four years and, with their credibility growing, looked to be headed towards eventual renewal, while the Liberal government had quietly dropped its plans for abolishing the GST and renegotiating the NAFTA. Crucially also, after a shaky start in 1994, serious and visible political efforts to come to grips with the fiscal situation culminated in the landmark "austerity" - as it would nowadays be labelled - budget of February 1995. The question of Quebec separation was settled, for a while, in October 1995 by a referendum in that province, though by an extremely slim margin.

${ }^{23}$ What they term "The rise and fall of the monetary conditions index" is discussed in more detail by Laidler and Robson (2004, pp 119-123)

${ }^{24}$ See, e.g. Pierre Duguay (1994), and Coletti et al. (1996), whose work was already in progress in 1994. And see also Duguay and Longworth (1998) for a retrospective account of Bank of Canada contributions to these developments, which dated back to the mid-1980s
} 


\section{LAIDLER Establishment of Inflation Targeting in Canada}

MCI to the state of aggregate demand and inflation expectations, so as to keep actual inflation on track; and clear communications to the public at large about its intentions here were intended to facilitate the economy's adjustment to those actions, in an early version of the use of "forward guidance" in the policy process, though this specific terminology was, of course, not then current.

The underlying theory here was surely faultless (at least by the standards of the time), but the MCI foundered in practice on a complicating factor whose significance even sophisticated private sector agents turned out to find hard to grasp (despite the Bank's repeated efforts to explain its significance): namely, that, in the very nature of things, the exchange rate was subject to more than one influence, and how an inflation targeting central bank should adapt interest rates to movements in this variable in order to keep inflation on track, depended on which of these was at work. For example, a tendency of the exchange rate to respond to financial market troubles elsewhere in the world - as when, for example, the 1995 Tequila crisis caused an international flight to the quality of the US dollar, weakening the Canadian exchange rate as a side effect - would, other things equal, require an offsetting change in Canadian interest rates to maintain monetary conditions constant. On the other hand, if the exchange rate movement was the result of changing demand conditions for Canadian exports, the appropriate response, again other things equal, would be to allow the resulting change in monetary conditions to offset this real shock, and hence not to respond to the exchange rate change with an interest rate movement.

Apparently unable to grasp this all important distinction (and, to be fair, even when it is grasped in principle, it can be hard to apply in practice) private agents began to anticipate mechanically in domestic financial markets what they believed the Bank's response to any change in the exchange rate was going to be if the MCI was to be held stable. They also began to complain about having been misled on occasions when the Bank disappointed them. The MCI, that is to say, rather than aiding the transparency with which monetary policy was conducted, actually became a source of opacity that hampered its effectiveness. There was a particularly difficult episode in 1998 involving dissonance among the Bank's initially announced conditional intentions towards, market expectations about, and the actual evolution of, monetary conditions. This dissonance had been created by the unexpected onset of the Russian crisis in the summer of that year, and in the wake of the criticism the Bank received as a result, it began to downplay the MCI, and in due course ceased its publication. As deputy governor Charles Freedman (2001) remarked:

While in my view monetary conditions remain a useful concept, the MCI has not proved to be especially helpful as a communications device vis-à-vis markets at times of uncertainty regarding the source of the shock causing the movement in the exchange rate. Thus, while the Bank continues to use the 
term "monetary conditions" in its description of policy, it places less emphasis on the MCI as a measure of these conditions. (p. 4)

\section{The controversial end of foreign exchange market intervention}

Also in 1998, in decisions associated with the above-mentioned Russian crisis, the Bank of Canada permanently suspended what, up till then, had been a routine policy of regular "symmetrical intervention" in the foreign exchange market, while that summer also saw what proved to be its last attempt to stabilise this market by way of a special intervention (though to this day the Bank still reserves it right to carry out such intervention in unspecified circumstances). ${ }^{25}$ All in all, then, these developments, alongside the disappearance of the MCI, meant that by the end of the 1990 s, the exchange rate had finally been deprived of the privileged position that it had earlier occupied in monetary policy making in Canada, and the Bank seemed to be following the advice of a future Governor, then in the private sector, to "develop an indifference towards the currency" (Stephen Poloz, 1997, p. 238).

This transition to a new dominant idea was not altogether smooth, however. It generated considerable controversy for a while. Beginning in 1998, certain commentators who had never been happy with inflation targeting in the first place, mainly because they had remained sceptical about the stability of the market determined flexible exchange rate that was by then widely understood to be necessary to support it, launched a vigorous campaign to have the inflation targeting regime scrapped. They wanted it replaced by some sort of rigidly fixed exchange rate arrangement - a Currency Board based on the US dollar, along Argentinian lines, was one suggestion, and the creation of a North American Monetary Union on the then brand new European model was another. ${ }^{26}$ Such proposals caused a considerable stir among the

\footnotetext{
25 "Symmetric intervention" involved the Bank in automatically buying its currency on a falling market and selling it on a rising market, not in order to influence the ultimate outcome, but to smooth the exchange rate's progress towards it. During the Russian crisis of the summer of 1998, foreign exchange rates were so volatile that, although the general direction of the exchange rate was downwards, it occasionally rallied for a few days. At such times the Bank found itself selling the currency at the same prices at which it had been buying only a few days earlier, thus creating confusion in the market about what its intentions actually were.
}

${ }^{26}$ See e.g. Courchene and Richard Harris (1999) and Herbert Grubel (1999). It is hard to resist the conclusion that there was an element of me-too-ism about the enthusiasm for such schemes. In the late 1990s the Argentinian currency board seemed to be stable and successful, having survived the tests posed for it by the Tequila crisis, and Europe was in the process of launching the Euro. And of course, the ups and downs of the Canadian dollar since the advent of inflation targeting had helped perpetuate in some circles the very legitimate doubts about flexible exchange rate stability that the experience of the 1970s and 80s had created. An important element in the case against such fears was Bank of Canada Research (Robert Amano and Simon van Norden 1995) arguing that these variations largely reflected terms of trade effects, particularly those emanating from international commodity markets in general, and that for oil in particular, which played an independent role in what came to be called "the Bank of Canada" equation. This work proved not only to be replicable, but also to generate results that continued 


\section{LAIDLER Establishment of Inflation Targeting in Canada}

informed public, with some of their proponents (see e.g. Sherry Cooper 2001) going so far as to argue that spontaneous dollarization of the Canadian economy was already well under way and gathering speed, so that the formal and quick adoption by Canada of the US dollar as its domestic currency was the only viable monetary policy option left open. Bank of Canada researchers easily enough rebutted such allegations about the facts of the case (See John Murray and Powell 2002), however, and ultimately, as the exchange rate rebounded from its 2003 low - it even reached a high of $\$ 1.07$ for a day or so in 2006 - these schemes lost political traction.

Meanwhile, in 2001 the "interim" 2 percent inflation target that had been inherited from the impasse of 1993, and had then been renewed in 1998, was renewed once more, accompanied by an agreement between the Bank and the Department of Finance cast in language that, with only minor amendments, has been repeated in three subsequent renewals (2006, 2011 and 2016), In short, with the exchange rate finally deprived of its status as an occasionally competitive, not to say disruptive, target for monetary policy, the 2 per cent inflation targeting regime that we still know today was finally and credibly in place.

\section{The Marginalisation of the Monetary Aggregates}

A prominent feature of inflation targeting as practiced in Canada, and as analysed in such fundamental works on its underlying theory as Woodford (2003) is a complete lack of attention to the behaviour of monetary aggregates. At the other extreme, that behaviour and its control by the authorities was the intellectual and practical centrepiece of the gradualist monetary policies that dominated the late 1970s in Canada, not to mention the many variations on the same theme implemented elsewhere at about the same time. Thus, the, marginalisation of these variables in the policy process is a key element in any story about the development of inflation targeting in any jurisdiction.

Though it is sometimes suggested that policies centered on controlling money growth were universal failures in the $70 \mathrm{~s}$ and $80 \mathrm{~s}$, this is not quite true. In two jurisdictions at least, Germany and Switzerland, the local varieties, which were implemented with considerable flexibility and pragmatism, do seem to have helped to avoid the double-digit inflation that afflicted so many other economies. And they survived into the 1990s and even a little beyond. Thus the "monetary pillar" of the ECB's original policy framework was a direct intellectual descendent of the German experiment. But the outcome of monetary gradualism in Canada was less happy, and money growth targets were not nearly as durable there. As has already been noted, after 1975, policies centered on them at best succeeded in stabilising inflation over the

to hold as new data emerged. In particular, the oil price which had taken a positive coefficient for earlier years, when Canada was a net importer, switched signs, as it should have done, when Canada became a net oil exporter. For a further discussion, see Laidler and Robson (2004, pp. 164-167) 
following five years, before being summarily abandoned in the face of the exchange rate effects of the Volker disinflation in the U.S. - itself the consequence of a botched attempt by the Fed at gradually reducing inflation by targeting money growth.

\section{The implementation of monetary "gradualism"}

There is little controversy about the local reasons for the disappointing performance of Canada's gradualist experiment in money growth targeting (see e.g. Howitt 2001, 2012)), and they were already being perceptively documented by Couchene (e.g. 1977, 1981) while the program was still in place, To begin with, money growth contraction was introduced so gradually that it failed to generate any immediately obvious effects that might have helped it gain credibility. In addition, the economic significance of the particular aggregate being targeted, the rather narrow M1, kept changing as the experiment unfolded. This was partly because of the development at that time of new computing technology that affected the types of chequable deposits that banks could economically offer their customers, partly because of the incentives to adopt such innovations that high nominal interest rates generated by inflation were creating, and partly because of the effects on the policy significance of M1 induced by the very existence of the targeting program itself, an obvious (especially in hindsight) manifestation of what would later come to be called the "Lucas critique" and/or "Goodhart's law", but which Courchene (1977) called "the Heisenberg principle" citing Kenneth Boulding (1966) as the idea's originator.

Also central to Courchene's critique, and important to the longer run story, was his scepticism about the Bank of Canada's reliance on the sensitivity of the demand for money to the same short term interest rates that already served it as policy instruments as it implemented its program. In effect, the Bank's policy practice amounted to forecasting the price level and real income arguments of the demand for money function, inserting these along with its target for money growth into the relationship, and then solving for and setting the interest rate required to achieve the latter. It thus treated money growth as a passively endogenous demand-driven indicator of monetary policy's stance, and not as the critical causative factor in the inflationary process that the monetarist ideas on which it claimed to be basing its policy would have had it.

Even in the 1970s, that is to say, the Bank had already developed and was basing its actions on a view of the place of the monetary aggregates in the policy process which foreshadowed, in all of its essentials, the role (or rather lack thereof) accorded to them in today's standard model, a view that was intellectually incompatible with the policy regime it was trying to implement. Small wonder that the latter would prove to be ineffective. Especially following Woodford (2003), this passive view of money's role in the transmission mechanism is 


\section{LAIDLER Establishment of Inflation Targeting in Canada}

nowadays widely understood to imply that policy makers may safely ignore the monetary aggregates altogether, even as indicators of the stance of policy, and provides the theoretical basis for their virtual disappearance from today's mainstream policy discussions (see Freedman (2003), Howitt 2012). This implication was not fully appreciated in the 1980s and early '90s, however, and over the next decade or so, though they were never accorded a well-defined place in the practice of Bank of Canada policy, ideas about monetary aggregates continued to attract attention there, in sometimes logically inconsistent ways.

\section{Money in the Hanson Lecture and after}

A prime example here is the Hanson lecture itself. When he discussed the monetary policy transmission mechanism, Crow pointedly abstained from discussing any role for money, except for a single passing assertion that "disequilibrium between the supply and demand for money" (along with "non-price rationing" and "some mysterious "black box") had no role to play in this process. Instead, he described the

linkages between central bank actions and their ultimate effects on the economy ... as follows. The Bank of Canada, by increasing or decreasing the supply of settlement balances to financial institutions, directly influences the very shortest term interest rates in the Canadian money market. Movements in these rates in turn influence the whole spectrum of market and administered interest rates and rates of return on a wide variety of assets and liabilities and, through them, the exchange value of the Canadian dollar. The movements of various rates of return and the price of foreign exchange affect over time total spending in the economy." (Crow 1988a, p.9)

But, when it came to "The Use of Policy Guides," he nevertheless referred extensively to work then in progress at the Bank on the stability of various empirical relationships involving monetary aggregates - particularly those that showed narrow money to be an important leading indicator of real activity, and broad money of the inflation rate. The awkward question implicit here about how monetary aggregates can be useful leading indicators of output and inflation without also playing a causative role in their determination was simply not taken up.

These intellectual tensions were in due course recognised, of course, and in the early 1990s some Bank researchers did indeed take seriously the idea that money might play an active role in the policy-transmission mechanism (see Laidler and Robson 1993, pp. 116-119). Even so, earlier scepticism about this possibility also continued to be given its due in other pieces of Bank research, notably in an important study by Pierre Duguay (1994). This, while paying 
attention to money's indicator properties, nevertheless presented an empirically estimated formal model of the mechanisms outlined in the Hanson lecture from which money was totally absent, and which differed from today's standard model only in failing to include an explicit policy reaction equation akin to a Taylor rule. ${ }^{27}$ And money was missing altogether from the structure of the Bank's then new Quarterly Projection Model (Colletti et al. 1996), as it still is from ToTEM (terms of trade econometric model) that is QPM's direct intellectual descendent.

\section{The termination of research on the monetary aggregates}

In effect, then, from the early 1990s onwards, the Bank's research on money self-consciously followed two inconsistent tracks, one ignoring money and the other emphasising it, in what came to be called a "multiple paradigms" approach to monetary policy analysis (see e.g. Walter Engert and Selody 1998, David Longworth 2003, Laidler 1999, 2003b). Finally, in 2003, however, work on a possibly causative role for the monetary aggregates, and also on their usefulness as leading indicators, was to all intents and purposes abandoned, with the termination of the so-called "Blue Book" project that the Bank had set in motion in 1999. ${ }^{28}$

This project had been given the task of generating policy advice explicitly based on the aggregates' behaviour, as a counterweight to more conventional work, which by this time centered around the Bank's already mentioned, and by then conventional (calibrated rather than estimated) dynamic stochastic general equilibrium Quarterly Projection Model (QPM). Experience during the Blue Book project's four year lifespan seemed to confirm doubts about money's capacity to add anything useful to insights generated by the standard approach to

\footnotetext{
${ }^{27}$ Duguay and Poloz (1994), in what amounts to a companion piece to this paper, dealing specifically with the use of model-based projections in the Bank's policy decision making, describe the latter process as being "pragmatic . . . There are no simple rules, but rather a process of successive approximation anchored by a firm long term commitment to price stability" (p.197). Interestingly, neither of these papers refers to Taylor (1993).

${ }^{28}$ Note that the 1990s saw an evolution of the Bank of Canada's operating procedures which adapted them ever more closely to the requirements of practices based on today's standard model and also made them less obviously suitable for controlling money growth. First of all, in 1994, the focus of the Bank's operations to control interest rates was shifted from the market for three month treasury bills to that for overnight loans in the market for clearing balances, while reserve requirements were phased out. The electronic "large value transfer system" became the central feature of the clearing system at the end of the 1990s, with the Bank setting a target for the overnight rate ruling therein, fixing its discount rate at 25 basis points higher, and the interest rate on clearing balanced held with it 25 basis points lower than this target. After encountering difficulties with a policy of providing zero overnight balances to this market, the Bank took to providing an extremely low level of cash reserves, unrelated to the level of its interest rate target, to "lubricate" it. In 2000, the Bank also moved to a system of announcing its target for the overnight rate at regular (six week) intervals, rather than only as and when conditions seemed to require a change in this variable. The system in place since 2000 thus resembles, in all its essentials, the "corridor system" described by Woodford (2003, Ch. 3), as he acknowledges.
} 


\section{LAIDLER Establishment of Inflation Targeting in Canada}

inflation targeting embodied in QPM, supplemented in the Canadian case by the Bank's regular regional surveys of economic conditions, intentions and expectations. Policy recommendations emerging from the project seemed usually to be based as much on informal judgements about the economic situation, rather as on assessments explicitly derived from the behaviour of the aggregates. $^{29}$

It remains to be seen whether the Bank's 2003 decision to eliminate the monetary aggregates from its policy research and practice was wise for the longer run. John Stuart Mill's (1848) much quoted obiter dictum has it that

"There cannot . . . be a more intrinsically insignificant thing, in the economy of society, than money: . . . It is a machine for doing quickly and commodiously, what would be done, though less quickly and commodiously, without it: and like many other kinds of machinery, it only exerts a distinct and independent influence of its own when it gets out of order." (Mill (1848, (1872)) p. 488)

In the years running up to 2003, those of the so-called "great moderation", the machine in question, not least in Canada, was very much in order and functioning smoothly, and any influence of money on the real economy and the inflation rate could not help but be essentially invisible. One must wonder, however, whether the Bank's apparently final loss of interest in them was the result of overemphasising the evidence generated by this particular, and perhaps unusual, period of monetary tranquility. But for the moment, the monetary aggregates remain marginalised in discussions of Canada's inflation targeting regime, let alone in the day to day formulation of policy. 30

\section{Interacting Ideas and Events in Retrospect}

Despite the immediate distractions created by the Great Recession that began in 2007, the Bank of Canada made a substantial and systematic study of the possibilities for changing its policy

\footnotetext{
${ }^{29}$ Freedman (2003 pp. 137-140) gives an account of the Bank of Canada's Blue Book project and the reasons for its abandonment in the course of a wide ranging account of the declining attention paid in recent years to monetary aggregates by a central banks in general.

${ }^{30}$ In Canada, Ambler and Kronick (2018) have recently made the case for the Bank to pay more attention to the behaviour of monetary aggregates. In the U.K. Tim Congdon (e.g. 2012) continues to advocate a central role for broad money in both the analysis of macroeconomic behaviour and the conduct of monetary policy, as of course in Europe and the US do self-styled "market monetarist" bloggers such as Scott Sumner (The Money Illusion) and Lars Christensen (The Market Monetarist). In the US also, William Barnett (e.g. 2012), Michael Belongia and Peter Ireland (e.g. 2015) continue to promote the virtues of Divisia aggregates.
} 
regime, and making it more permanent in nature too, in 2011 (see Bank of Canada 2011). ${ }^{31}$ In particular, the options of lowering the targeted inflation rate, and/or of shifting to a target time path for the price level, received serious consideration. But from 1995 to 2007 when the recession started, actual inflation had averaged almost exactly 2 percent, while that event's local version was the first to occur in Canada since 1991. It is not surprising then, that, in 2011, the authorities decided to put any ambitions for establishing a new and more permanent regime on hold, and to stick with the existing one for a further five years, albeit embellished with an explicit recognition of the need for some flexibility in the face of financial turbulence. It had simply not been possible to establish with sufficient confidence that replacing it with something more ambitious and permanent would yield worthwhile gains.

Thus a target that had been set two decades earlier as an interim goal along the path from uncomfortably high inflation to a state of price stability, and had been supported by a monetary policy framework that, by the early 2000s' had evolved into rather close conformity to what was by then the academic literature's standard macroeconomic policy model, gained a further, albeit still temporary, lease on life. This paper has tried to account for how all this came about, paying particular attention to the ways in which economic ideas influenced policies, whose consequences, in their own turn, sometimes caused those ideas to be modified or even replaced altogether; and so on, in a recursive process.

\section{The influence of changing ideas}

Early in the story, when Governor Crow delivered the Hanson Lecture, competing ideas about the stability of inflation were in circulation in Canada. A substantial body of academic opinion had it that any fully anticipated inflation rate could be stable over time, but the Governor and his colleagues held a different and older view: namely, that anything short of price stability would likely generate expectations about inflation's future behaviour that would undermine the credibility of monetary policy and the stability of its outcomes. This latter idea initially dominated the conduct of monetary policy. But by 2001, say, after a decade of what used to be called "creeping" inflation deliberately and successfully supported by policy, it became clear that to base policy on the idea that low inflation can be stable had been a step in the right

\footnotetext{
${ }^{31}$ The recession in Canada was sharp, though the financial system remained stable-beyond some serious but localised 2007 problems in the market for asset backed commercial paper. The Bank of Canada nevertheless introduced a number of special liquidity schemes, and also for a while found it necessary to provide extra settlement balances to the clearing system, though there was no resort to quantitative easing based on outright asset purchases. The Bank also gave conditional forward guidance about the likely duration of its resort to rock bottom interest rates that seems to have worked well - unlike its earlier efforts based on the MCI discussed earlier.
} 


\section{LAIDLER Establishment of Inflation Targeting in Canada}

direction. And this idea's subsequent confirmation by further experience has continued to provide a firm basis for inflation targeting's longevity in Canada.

Even so, it was not policies based on the Bank of Canada's beliefs about the instability of inflation itself that almost derailed its program in 1990-91, but rather measures derived from long-held views on the potentially destabilising effects on inflation of exchange rate movements. The influence of these ideas also began to fade after 1993, and essentially vanished from the policy scene after 1998, again under the influence of events; and again discredited ideas were replaced by competing beliefs drawn from the academic literature, in this instance Friedman's (1953) analysis. These had it that domestic monetary stability would itself support exchange rate stability, and suggested that supplementary attempts to influence the exchange rate directly were likely to interfere with that domestic stability. The growing dominance of these ideas among policy makers from the early 1990s onwards also contributed to the success, and hence to the credibility and longevity, of Canadian inflation targeting.

\section{The feedback from events to ideas}

In these two instances, then, ideas originating outside of policy making circles began to influence policy under pressure from events, and proved robust in the face of the experience that their application then generated. But the intellectual traffic was not one way. The Bank of Canada's relocation of monetary policy's "place to stand" from an intermediate variable - such as a target for money growth - to an ultimate one - a goal for the behaviour of the price level itself - represented a major break with much of the conventional academic wisdom of the 1980s, and even when the pursuit of price stability gave way to the maintenance of low inflation, this emphasis on an ultimate policy goal remained in place.

Among academics, the prevailing view well in to the 1990s had remained that the complicated and drawn out lag structure of the transmission mechanism would render such an approach to monetary policy dangerously prone to instability. Nowadays, however, it is just as much conventional academic wisdom that confidence among economic agents about the price level's future behaviour, based upon credible policy targets, provides a firm anchor for the control of inflation. In this instance, then, academic discourse has imported a point of view that was initially the property of policy makers.

\section{Concluding Comment}

The history documented in this paper thus suggests that the easy coexistence of a standard formal model and well established policy practice that marks today's inflation targeting regime in Canada (as elsewhere) did not emerge from a straightforward process involving the creation of a theory, followed by its application to practice. Rather what seems to have happened is that, 
in the 1990s, two parallel developments, one originating in the academic literature, and the other grounded in practical policy experience, interacted and ultimately came into harmony with one another, in an altogether more complicated and untidy process. How long-lived this harmony will prove to be is a question for another time, but because economic theory continues to evolve, and economic events continue to surprise, its durability should not necessarily be taken for granted.

\section{References}

Akerlof, G. and R. Shiller (2009) Animal Spirits Princeton N.J. Priceton University Press

Akerlof, G, W. T. Dickens W. T and G. L. Perry (1996) The macroeconomics of low inflation. Brookings Papers on Economic Activity (1) 1-59

Amano R. and S. van Norden (1995) Terms of trade and real exchange rates: The Canadian evidence. Journal of International Money and Finance, 14 (April) 83-104

Ambler, S. and J. Kronick (2017) Navigating Turbulence, Canadian Monetary Policy since 2004, Toronto, C. D. Howe Institute

Bank of Canada (1991) Targets for reducing inflation: press release. Bank of Canada Review March, 5-6

Bank of Canada (2001) Joint Statement of the Government of Canada and the Bank of Canada on the Renewal of the Inflation Control Target, Ottawa, Bank of Canada (Press Release)

Bank of Canada (2011) Renewal of the Inflation Control Target: Background Information November 2011 Ottawa, Bank of Canada

Bank of Canada (2016) Joint Statement of the Government of Canada and the Bank of Canada on the Renewal of the Inflation Control Target Ottawa, Bank of Canada, (Press Release)

Barnett, W. (2012) Getting it Wrong: How Faulty Monetary Statistics Undermine the Fed, the financial system and the Economy, Cambridge MA. MIT Press

Barro, R. J. (1996) Inflation and economic growth. Bank of England Quarterly Bulletin 35; 166-76

Belongia, M. and P Ireland (2015) Interest rates and money in the measurement of monetary policy, Journal of Business and Economic Statistics 33:2 255-269

Bouey, G. K. (1975) Remarks to the $4^{\text {th }}$ annual meeting of the Canadian Chamber of Commerce, Sept. 22, mimeo

- (1982) Monetary policy - finding a place to stand. Per Jacobsson Lecture. Bank of Canada Review (September) 3 - 25

Boulding, K. (1966) The economics of knowledge and the knowledge of economics, American Economic Review, 56 (Mar.) 1-13

Christensen L (various dates) The Market Monetarist, www. market monetarist.com/ 
Coletti, D., B. Hunt, D. Rose, and R Tetlow (1996) The Bank of Canada's new quarterly projection model; Part 3, The dynamics of the model: QPM, Technical Report 75, Ottawa, Bank of Canada

Congdon, T. (2012) Money in a Free Society, London, Encounter Books

Cooper, S. (2001) Time for a U.S. loonie. National Post, November 9, 13

Courchene, T. J. (1975) Money, Inflation and the Bank of Canada : an Analysis of Canadian Monetary Policy from 1970 to Early 1975, Toronto, C. D. Howe Institute

Courchene, T. J. (1976) Monetarism and Controls: the Inflation Fighters, Toronto, C. D. Howe Institute

Courchene, T. J. (1977) The Strategy of Gradualism: An analysis of Bank of Canada Policy from Mid-1975 to Mid-1977, Toronto, C. D. Howe Institute

Courchene, T. J. (1981) Money, Inflation and the Bank of Canada Volume II: An Analysis of Monetary Gradualism 1975-1980, Toronto, C. D. Howe Institute

Courchene, T. J. (1990a) Zero means almost nothing: towards a preferable inflation and macroeconomic policy. Queens University Quarterly 97 (Winter) 543-61

Courchene, T. J. (1990b) Rethinking the macro mix: the case for provincial stabilization policy, in R. York (ed.) Taking Aim: the Debate on Zero Inflation, Toronto, C. D. Howe Institute

Courchene, T. J. and R. G. Harris (1999) From fixing to monetary union: options for North American currency integration, Commentary 127, Toronto, C. D. Howe Institute

Crawford A, and A Harrison (1998) Testing for downward rigidity in nominal wage rates, in Price Stability, Inflation Targets and Monetary Policy Ottawa, Bank of Canada

Crow J. W. (1988a) The work of Canadian monetary policy. Eric J. Hanson Memorial Lecture, delivered at the University of Alberta Jan. 18 ${ }^{\text {th }}$ Edmonton, Department of Economics, University of Alberta (reprinted Bank of Canada Review April 31-37)

Crow J. W. (1988b) Some responsibilities and concerns of the Bank of Canada, Bank of Canada Review June

Crow J. W. (2002) Making Money: an Insider's Perspective on Finance, Politics and Canada's Central Bank, Toronto; John Wiley

Drummond, D., (2010) Canadian monetary policy: if it isn't broken can it be fixed? Verbatim, Toronto, C. D. Howe Institute

Duguay, P. (1994) Empirical evidence on the strength of the monetary transmission mechanism in Canada: an aggregate approach, Journal of Monetary Economics 33, 39-61

Duguay, P. and D. Longworth (1998) Macroeconomic models and policy making at the Bank of Canada, Economic Modelling 15 (3) 357-375 
Duguay, P. and S. Poloz (1994) The role of economic projections in Canadian monetary policy formation, Canadian Public Policy 20 (June) 189-99

Engert W. and J Selody (1998) Uncertainty and competing paradigms of the transmission mechanism, Working Paper 98 -7 Ottawa, Bank of Canada

Fisher I. and H. R. L. Cohrssen (1934) Stable Money, a History of the Movement, New York, Adelphi Company

Forder, J. (2014) Macroeconomics and the Phillips Curve, Oxford, Oxford University Press

Fortin, P. (1990) Do we measure inflation correctly? In R. G. Lipsey (ed) Zero Inflation: the Goal of Price Stability, Toronto, C. D. Howe Institute

Fortin, P. (1995) Canadian wage settlement data, Universite de Quebec a Montreal, unpublished mimeo

Fortin, P. (1996) Presidential address: the great Canadian slump, Canadian Journal of Economics29 (Nov.) 761-87

Freedman C. (1994) The use of indicators and the monetary conditions index in Canada, in T. Balino and J Cottarelli (eds.) Frameworks for Monetary Stability: Policy Issues and Country Experiences, Washiongton D.C.; IMF

Freedman C. (2001) Recent developments in the framework for the conduct of monetary policy in Canada, Canadian Business Economics (3) 3-6

Freedman C. (2003) From money targeting to inflation targeting: the change in the role of money in the conduct of monetary policy, in R. Leeson (ed.) David Laidler's Contributions to Economics, Houndmills, Palgrave Macmillan

Freedman C. and T. Macklem (1998) A comment on "the great Canadian slump" Canadian Journal of Economics, 31 (Aug.) 646-665

Friedman, M (1953) The case for flexible exchange rates, in Essays in Positive Economics, Chicago, University of Chicago Press

Friedman, M (1960) A Program for Monetary Stability, New York, Fordham University Press

Friedman, M (1968) The role of monetary policy, American Economic Review, 58, 1- 18

Goodhart, C.A.E. (2010) The political economy of inflation targets: New Zealand and the U.K in R. Leeson (ed.) Canadian Policy Denbates and CaseStudies in Honour of David Laidler Houndmills, Palgrave Macmillan

Grubel, H. (1999) The case for the Amero: The economics and politics of a North American monetary union, Critical Issues Bulletin (September) Vancouver, the Fraser Institute

Haberler, G. (1961) Inflation, its Causes and Consequences, Washington DC, The American Enterprise Institute

Hogan S. (1998) What does downward nominal rigidity imply for monetary policy? Canadian Public Policy 24 (Dec.) 513-25 
Howitt, P. W. (1986) Monetary Policy in Transition: a Study of Bank of Canada Policy 198285, Toronto, C. D. Howe Institute

Howitt, P. W. (1990) Zero-inflation as a long-run target for monetary policy, in R. G. Lipsey (ed.) Zero Inflation: the Goal of Price Stability, Toronto, C. D. Howe Institute

Howitt, P. W. (2001) Learning about monetary theory and policy, Providence RI, Brown University, mimeo

Howitt, P. W. (2012) What have central bankers learned from modern macro theory Journal of Macroeconomics, 34 (March) 11-22

Jarrett, P. and J. Selody (1982) The productivity nexus in Canada 1963-1979, Review of Economics and Statistics, 64 (Aug.) 361-67

Johnson, D. (1990) An evaluation of the Bank of Canada's zero inflation target: Do Michael Wilson and John Crow agree? Canadian Public Policy 16 (Sept.) 308-25

Krugman, P. (1996) Stable prices and fast growth, just say no The Economist, August 31st. 19.

Laidler, D. (1990) The zero-inflation target: an overview of the economic issues, in R. G. Lipsey (ed.) Zero Inflation: the Goal of Price Stability Toronto, C. D. Howe Institute

Laidler, D. (1999) Passive money, active money, and monetary policy, Bank of Canada Review (Summer) 15 - 25

Laidler, D. (2003a) The role of the history of economic thought in modern macroeconomics, in P. Mizen (ed.) Monetary History, Exchange Rates and Financial Markets, Essays in Honour of Charles Goodhart, Volume Two, Cheltenham, Edward Elgar

Laidler, D. (2003b) Monetary policy without money: Hamlet without the ghost, in Bank of Canada, Macroeconomics, Monetary Policy, and Financial Stability, A Festschrift in Honour of Charles Freedman, Ottawa, Bank of Canada

Laidler, D. (2017) Economic ideas, the monetary order and the uneasy case for policy rules, Journal of Macroeconomics 54, 12-33

Laidler, D. and W. B. P. Robson (1993) The Great Canadian Disinflation: the Economics and Politics of Monetary Policy in Canada, 1988-93, Toronto, C. D. Howe Institute

Laidler, D. and W. B. P. Robson (2004) Two Percent Target: Canadian Monetary Policy Since 1991 Toronto, C. D. Howe Institute

Laidler, D. and G. W. Stadler (1998) Monetary explanations of the Weimar Republic's hyperinflation: some neglected contributions to the contemporary German literature, Journal of Money, Credit and Banking 30 (Nov.), as repr. in D. Laidler Macroeconomics in Retrospect, Cheltenham, Edward Elgar, 2004

Leijonhufvud, A. (1977) Costs and consequences of inflation, in G.C, Harcourt (ed.) The Microeconomic Foundations of Macroeconomics, London, Macmillan 
Lipsey, R. G. (1963) An Introduction to Positive Economics, London, Weidenfeld and Nicolson Lipsey, R. G. (1990) The political economy of inflation control, in R. G. Lipsey (ed.) Zero Inflation: the Goal of Price Stability, Toronto, C. D. Howe Institute

Lipsey, R. G. (ed.) (1990) Zero Inflation: the Goal of Price Stability, Toronto, C. D. Howe Institute

Longworth, D. (2003) Money in the Bank (of Canada) Technical Report 93, Ottawa, Bank of Canada

Longworth, D. and S. Poloz (1986) A comparison of alternative monetary policy regimes in a small dynamic open economy simulation model, Technical Report No. 42, Ottawa, Bank of Canada

Lucas, R. F. (1989) The Bank of Canada and zero inflation: a new cross of gold? Canadian Public Policy 15 (Mar.) 84-93

Mill, J. S. (1848) The Principles of Political Economy with Some of Their Applications to Social Philosophy ( $7^{\text {th }}$ ed., 1872) as repr. Ed. W. J. Ashley, London, Longman Green 1920

Murray, J. and J. Powell (2002) Is Canada dollarized? Bank of Canada Review Autumn, 3-12

Nurkse, R. (1944) International Currency Experience, Geneva, League of Nations Phelps, E.

S. (1967) Phillips curves, expectations of inflation and optimal unemployment over time, Economica,NS 34 (Aug) 254-81

Nurkse, R. (1972) Inflation Policy and Unemployment Theory: The cost Benefit Approach to Monetary Planning, New York, W.W. Norton

Poloz, S. (1997) A comment (on J. Grant, The Bank of Canada's operating framework) in D. Laidler (ed.) Where We Go from Here, Toronto, C. D. Howe Institute

Powell, J. (2009) The Bank of Canada of James Elliott Coyne: Challenges, Confrontation and Change, Montreal and Kingston, McGill-Queesn University Press

Purvis, D. D. (1990) The Bank of Canada and the pursuit of price stability, in R. G. Lipsey (ed.) Zero Inflation: the Goal of Price Stability, Toronto, C. D. Howe Institute

Ragan, C. (1998) On the believable benefits of low inflation Working Paper 98-15 Ottawa Bank of Canada

Royal Commission on Banking and Finance (The Porter Commission) (1964) Report, Ottawa, The Queen's Printer

Royal Commission on the Economic Union and Development Prospects for Canada (The Macdonald Commission), (1985) Report (2. Vols.) Ottawa, Minister of Supply and Services, Canada

Scarfe B. L. (1988) Foreword, to Crow (1988a), Edmonton, Department of Economics, University of Alberta. 
Schultze C. L. (1959) Study Paper No. 1, in Joint Economic Committee, Recent Inflation in the United States Washington D. C. Government Printing Office

Selody, J. (1990) The goal of price stability: a review of the issues, Technical Report 54 (May) Ottawa, Bank of Canada

Simons, H. (1936) Rules versus authorities in monetary policy, Journal of Political Economy 44 (Feb.) 1-30

Sumner, S. (various dates) The Money Illusion, www.themoneyillusion.com/

Svensson, L. E. O (1999) Inflation targeting as a monetary policy rule, Journal of Monetary Economics 43, 607-654

Tavlas, G. (2015) In old Chicago: Simons, Friedman and the development of monetary policy rules, Journal of Money, Credit and Banking, 47 (Feb.) 99-121

Taylor, J. (1993) Discretion versus policy rules in practice, Carnegie Rochester Series on Public Policy 39, 195-214

Thiessen, G. (1995) Uncertainty and the transmission mechanism of monetary policy in Canada: The Hermes-Glendon Lecture, as reprinted in G. Thiessen, The Thiessen Lectures, Ottawa, Bank of Canada 2001

Thiessen, G. (1999) Then and now: the change in views on the role of monetary policy since the Porter Commission: The Tony Hampson Memorial Lecture, as reprinted in G. Thiessen, The Thiessen Lectures, Ottawa, Bank of Canada, 2001

Thornton D. (1996) The costs and benefits of price stability: an assessment of Howitt's rule, Federal Reserve Bank of St. Louis Review (March/April) 23-38

Tobin, J. (1972) Inflation and unemployment, American Economic Review 62 (March) 1-18

Woodford, M. (2003) Interest and Prices: Foundations of a Theory of Monetary Policy, Princeton N.J. Princeton University Press 